\title{
Ruda-Skroda. Przyczynek do dziejów rudnictwa żelaza na Wysoczyźnie Kolneńskiej w średniowieczu i na początku doby nowożytnej
}

\author{
Elżbieta Kowalczyk-Heyman
}

Wysoczyzna Kolneńska, tak jak całe Mazowsze, poza piaskiem, żwirem, gliną i wapnem łąkowym, jest w zasadzie pozbawiona surowców mineralnych. Wyjątkiem są złoża rudy żelaza, popularnie zwanej rudą darniową. Ich występowanie jest bardzo łatwo zauważalne. Świadczy o tym m.in. kolor wody i rodzaj roślinności. Złoża rudy darniowej formowały się w zbiornikach sedymentacyjnych, w zasięgu oddziaływania wód gruntowych, w strefie wegetacji roślin, w podmokłych dolinach rzek, torfowiskach niskich, bagnach i mokradłach, przy czym istotne znaczenie miało tu występowanie piasków sandrowych ${ }^{1}$. Ze względu na płytkie zaleganie rudy $(0,1-0,3 \mathrm{~m}$ pod powierzchnią gruntu) bez kłopotu można było ustalić zasięg i jakość jej pokładów. Osiągają one miąższość 0,3-0,5 m, wyjątkowo $1 \mathrm{~m}$. Oblicza się, że z $1 \mathrm{~km}^{2}$ można pozyskać około $44,5 \mathrm{t}$ rudy. Ruda darniowa ma ponadto tę ważną cechę, że jej złoża są odnawialne, a jej powstawanie jest procesem ciągłym, o ile środowisko nie uległo degradacji, w szczególności jeśli nie doszło do zmiany stosunków wodnych² ${ }^{2}$.

$\mathrm{Na}$ Mazowszu największe złoża rudy darniowej zarejestrowano w Puszczy Kurpiowskiej, dawnej Zagajnicy. Na mniejsze można natknąć

\footnotetext{
1 T. Ratajczak, J. Skoczylas, Polskie darniowe rudy żelaza, Kraków 1999, s. 12-16, 52-53, 55; por. też M. Radwan, Rudy, kuźnice i huty żelaza w Polsce, Warszawa 1963, s. 19-45; M. Kowalkowski, Blaski i cienie hutnictwa żelaza na ziemiach polskich. Refleksje historyczne, cz. 1: Od zarania dziejów do roku 1939, Częstochowa 1989, s. 19-20, 15-26.

2 T. Ratajczak, G. Rzepa (Górnictwo i hutnictwo darniowych rud żelaza na Mazurach i ziemi piskiej, „Znad Pisy”, 9, 2000, s. 206) podali, iż w trakcie badań przeprowadzonych w latach 1996-1998 okazało się, że na skutek melioracji przeprowadzonych na północno-wschodnim Mazowszu została zniszczona znaczna część nagromadzeń rud darniowych, a zachwianie naturalnego reżimu fizyko-chemicznego spowodowało przerwanie procesu narastania pokładów.

3 Nieuprawniony był pogląd jednej z badaczek, interpretującej ogniska kowalskie jako ślady po paleniskach „do wysięku żelaza”, E. Twarows-
}

się wszędzie. Te ostatnie nie były z reguły rejestrowane przez służbę geologiczną przed drugą wojną światową i po jej zakończeniu, ale $\mathrm{z}$ powodzeniem były wykorzystywane $\mathrm{w}$ średniowieczu i czasach nowożytnych przez rudników wytapiających żelazo.

$\mathrm{Na}$ Wysoczyźnie Kolneńskiej, obszarze naszego zainteresowania, w kilku miejscach mamy poświadczone występowanie rudy darniowej, intensywnie wydobywanej i przerabianej w średniowieczu i w dobie nowożytnej. Tak było w zabagnionych dolinach Skrody (lewego dopływu Pisy), Wissy (prawego dopływu Biebrzy) oraz w bagiennej puszczy Dybła, porastającej między dolnym Łekiem (dzisiejszym Ełkiem) i Biebrzą. Dlatego też dziwi fakt, że w trakcie dotychczasowych badań archeologicznych nie zarejestrowano na tym obszarze miejsc wydobywania rudy i wytopu żelaza (dymarki, piece). Jedynie na dwóch wczesnośredniowiecznych stanowiskach w trakcie badań wykopaliskowych natrafiono na ślady dalszej obróbki kowalskiej surówki żelaznej pozyskanej w trakcie takiego wytopu ${ }^{3}$. Pierwsze znajdowało się w kompleksie osadniczym w Truszkach-Zalesiu, gm. Kolno, na osadzie przygrodowej (stan. 4 „Nikienki”) $)^{4}$, położonej na lewym

ka, Mały Ptock - legendy i archeologia, „Ziemia Łomżyńska”, 2, 1986 , s. 85. Z mitem tym rozprawił się wiele lat wcześniej L. Rauhut (Studia i materiały do historii starożytnego i wczesnośredniowiecznego hutnictwa żelaza w Polsce, w: Studia z dziejów górnictwa i hutnictwa, t. 2, red. J. Pazdur, Wrocław 1957, s. 193-194).

4 Jest to osada na stan. 4 „Nikienki” datowana roboczo na X-XI w. Zob. E. Marczak, Na rozdrożu kultur. Badania archeologiczne w Truszkach Zalesiu, gm. Kolno, woj. podlaskie, w: Stan badań archeologicznych na pograniczu polsko-białoruskim od wczesnego średniowiecza po czasy nowożytne, red. H. Karwowska, A. Andrzejewski, Białystok 2006 , s. 97; taż, Średniowieczne osady wśród tąk nad Wincentą. Zaplecze gospodarcze grodziska w Truszkach Zalesiu, „Zeszyty Kolneńskie”, 2, 2007, s. 10-11; taż, „Nikienki” czyli Prusowie na Mazowszu? Wstępne wyniki badań archeologicznych w Truszkach Zalesiu, woj. 
brzegu Wincenty - lewego dopływu Pisy. Drugie odsłonięto na osadzie przygrodowej w $\mathrm{Ma}$ łym Płocku ${ }^{5}$ położonej na lewym brzegu Czetny, prawego dopływu Narwi. Powyższy stan jest wynikiem braku kompleksowych badań wykopaliskowych średniowiecznych stanowisk związanych $\mathrm{z}$ rudnictwem żelaza na tym obszarze ${ }^{6}$.

Równie źle przedstawia się stan poszukiwań powierzchniowych. Badania prowadzone w programie Archeologicznego Zdjęcia Polski (dalej: AZP) nie zostały poprzedzone kwerendą źródeł pisanych, map historycznych oraz nazewnictwa miejscowego, terenowego i wodnego wskazujących na miejsca występowania rudy, jej wydobywania i przerabiania. Spowodowało to, że prowadzący je archeolodzy nie objęli szczegółowymi poszukiwaniami miejsc, w których dowodnie od XV w. znajdowały się młyny rudne i rudy - kuźnice żelaza ${ }^{7}$. Tych zaś na Wysoczyźnie Kolneńskiej było co

podlaskie, w: Przez granice czasu. Księga jubileuszowa poświęcona Profesorowi Jerzemu Gąssowskiemu, red. A. Buko, W. Duczko, Puttusk-Warszawa 2008, s. 119-127 (Acta Archaeologica Pultuskiensia, 1); taż, Niezwykłe odkrycie zwykłej ziemianki. Badania archeologiczne w Truszkach Zalesiu w 2010 roku, ,Zeszyty Kolneńskie”, 5, 2010, s. 86-91; taż, Truszki-Zalesie, st. 4 (Nikienki), woj. podlaskie. Badania w latach 2004-2005, 2007-2010, „Światowit”, 8 (49), fasc. B, 2011, s. 273-275. Pojawiający się w tych publikacjach pogląd, że była to osada hutniczo-kowalska, jest przedwczesny. Odnalezione tu gliniane dysze mogły być częścią miechów służących do podsycania żaru w paleniskach kowalskich. Nie natrafiono natomiast na żadne fragmenty glinianej konstrukcji dymarek i kloców żużlu. Kompleksu tego nie należy wiązać z osadnictwem pruskim. Jedynym dowodem na to podniesionym przez tę badaczkę miałaby być zanotowana wspótcześnie nazwa terenowa Nikienki, która mogła powstać dopiero w XVIIIXIX w. Por. E. Kowalczyk-Heyman, Nikienki - o niebezpieczeństwach niesionych przez zbyt pochopne interpretacje toponomastyczne dla badań nad osadnictwem wczesnośredniowiecznym, „Onomastica”, 53, 2008/2009, s. 222-232.

5 E. Twarowska, Maty Płock, gm. loco, stan. 2 [osada], w: Informator Archeologiczny. Badania rok 1979, Warszawa 1980, s. 263-264; taż, Mały Płock, gm. loco, stan. 2 [osada], w: tamże, s. 167-168; taż, Mały Ptock - legendy, s. 85-86. Założenie tej osady jest umiejscawiane $w X$ w., ale nie przedstawiono na to żadnych dowodów. Datowanie to i nieuprawnione interpretacje odsłoniętych znalezisk zaczęły żyć własnym życiem za pośrednictwem wtórnej, pełnej błędów pracy Czesława Brodzickiego i obrosły kolejnymi, postulatywnymi ustaleniami i domysłami w artykułach Kazimierza Pacuskiego i Marii Przytockiej. C. Brodzicki, Ziemia tomżyńska do 1529 roku, Warszawa 1999, s. 59-60; K. Pacuski, M. Przytocka, Z dziejów Małego Płocka, „Studia Łomżyńskie”, 15, 2004, s. 131; K. Pacuski, Mały Ptock. Zarys dziejów do 1526 roku, w: Dzieje parafii i kościoła pod wezwaniem Znalezienia Krzyża Świętego w Małym Płocku, red. M. Przytocka, najmniej kilka. W Radziłowie u zbiegu Słuczy i Kubry (prawy dopływ Wissy), ruda powstała w 1455 r. ${ }^{8}$ Ruda koło Grajewa, nieczynna już w 1535 r., pozostawiła po sobie staw Rudny9. Kolejna Ruda posadowiona była przy ujściu Dybły do Łeku, gdzie z czasem powstała wieś Ruda $^{10}$. Interesujące nas Ruda-Skroda i Rudka-Skroda położone były w dolnym biegu Skrody, około 3 i $1 \mathrm{~km}$ od jej ujścia do Pisy. Zapewne w pobliżu istniała jeszcze inna, niezlokalizowana Ruda ${ }^{11}$. W konsekwencji miejsca te nie zostały odnotowane na kartach AZP.

Przedmiotem poniższych rozważań będą dzieje dwóch kuźnic: Rudy-Skrody i Rudki-Skrody, położonych około $8 \mathrm{~km}$ na zachód od Małego Płocka. Dzieli je odległość około $2 \mathrm{~km}$, przy czym druga wieś leży w dół rzeki od pierwszej. Jakkolwiek początki obu wsi wiązane są z pierwszą połową XV w., to ich nazwy zachowane źródła pisane odnotowały znacznie później. Nie sądzę bowiem, aby z którąś z tych

Mały Płock 2013, s. 45 (Folia Ecclesiastica Pultoviensia, 6). Faza osady ze śladami pracowni kowalskich jest datowana na XII-XIII w.

${ }^{6}$ Jedyne badania wykopaliskowe takiego stanowiska w Zbójnej wsi położonej w pobliskiej Puszczy Kurpiowskiej - przeprowadził w latach 1966-1968 Tadeusz Żurowski. Opublikował on kilka sprawozdań z tych badań o prawie identycznej, ogólnikowej treści: T. Żurowski, Średniowieczna kuźnica w Zbojnie, pow. Kolno, w: Sprawozdania z badań archeologicznych przeprowadzonych w 1966 r. na obszarze województwa białostockiego przez: Muzeum w Białymstoku / Dziat Archeologiczny i Woj. Konserwator Zabytków Archeologicznych / Państwowe Muzeum Archeologiczne w Warszawie, Muzeum Regionalne w Łomży, Białystok 1966, s. 26-28 (mps powielany na prawach rękopisu); tenże, Zbójno, pow. Kolno [kuźnica], w: Informator Archeologiczny. Badania rok 1967, Warszawa 1968, s. 384-385; tenże, Ślady średniowiecznej kuźnicy w Zbójnie, pow. Kolno, , Rocznik Białostocki", 8, 1968, s. 415-416; tenże, Zbójna, pow. Kolno [kuźnica], w: Informator Archeologiczny. Badania rok 1968, Warszawa 1969, s. 378-380.

7 W tym miejscu chciałabym zwrócić uwagę na anachroniczne nazywanie tych obiektów hutami, co jest spolszczonym zapożyczeniem z języka niemieckiego. Prawie do końca XVIII w. w staropolszczyźnie huta oznaczała wyłącznie zakład produkujący szkło. W tym czasie dla nazwania polskiej rudy-kuźnicy używano słowa hamernia, również zapożyczonego z języka niemieckiego.

8 Metryka Koronna [dalej: MK], k. 125v, 335. Wszystkie wypisy ze średniowiecznych źródeł archiwalnych pochodzą z kartoteki Zakładu Atlasu Historycznego Instytutu Historii PAN w Warszawie [dalej: ZAH IH].

9J. Wiśniewski, Dzieje osadnictwa w powiecie grajewskim do połowy XVI w., w: Studia i materiaty do dziejów powiatu grajewskiego, t. 1 , red. M. Gnatowski, H. Majecki, Warszawa 1975, s. 182.

10 Tamże.

11 Por. niżej, s. 90-92. 
kuźnic można było wiązać zapis Rwda (Ruda) z 1509 r. ${ }^{12}$

Pierwsza $\mathrm{z}$ interesujących nas wsi przybrała przed 1578 r. nazwę Skroda Ruda (Scroda Ruda $)^{13}$, choć jeszcze w 1693 i 1714 r. oraz na mapie Johanna Christopha von Textora nosi tylko nazwę Ruda' ${ }^{14}$. W 1740 r. jest to Ruda Skroda ${ }^{15}$, a w latach 1783-1784 Ruda mtyn ${ }^{16}$. $\mathrm{Na}$ początku XIX w. (1827 r.) pojawił się ponownie zapis Ruda skroda ${ }^{17}$, a obecnie Ruda-Skroda. Nazwa drugiej wsi, w błędnym zapisie Rutka, znana jest dopiero $\mathrm{z}$ lat $1783-1784^{18}$, ale równocześnie, na mapach Karola Perthéesa i Johanna Christopha von Textora, odnotowano prawidłowy zapis $R u d k a^{19}$. W spisie miejscowości z 1827 r. jest to Rudka skroda ${ }^{20}$, a obecnie Rudka-Skroda.

W obecnej postaci nazwy obu wsi to dwuczłonowe, zestawione nazwy złożone. Ich drugi człon jest ponowieniem od nazwy wodnej, czyli od rzeki Skrody, nad którą leżą obie wsi. Ma on charakter wyróżniający, topograficzno-lokalizujący. Człony pierwsze obu nazw mają charakter utożsamiający. W przypadku nazwy pierwszej człon Ruda to nazwa kulturowa, poświadczająca istnienie tu młyna rudnego i rudy-kuźnicy ${ }^{21}$. Stąd jednostkowo pojawia się w miejsce Rudy nazwa Mtyn, która jest także nazwą kulturową. W przypadku pierwszego członu drugiej nazwy, Rudka, możemy mieć do czynienia z nazwę zdrobniałą, utworzoną od nazwy sąsiedniej wsi lub z nazwą kulturową, określającą mniejszy obiekt produkcyjny.

12 Archiwum Główne Akt Dawnych [dalej: AGAD], Księgi purtuskie grodzkie testamenta 1, 393. Por. niżej, s. 90-92.

13 Polska XVI wieku pod względem geograficzno-statystycznym, t. 5 : Mazowsze, wyd. A. Pawiński, Warszawa 1895, s. 274, 1578 r. (Źródła Dziejowe, 16, dalej: ŹDz 16). Korzystałam z egzemplarza skolacjonowanego z rękopisem znajdującym się w ZAH IH.

${ }^{14}$ Archiwum Diecezjalne w Płocku, Akta Wizytacji [dalej: ADP, AW] z 1693 r., sygn. 47, k. 404, 405; ADP, AW z 1714 r., sygn. 46, k. 389; J.Ch. von Textor, Topographisch-Militaerische-Karte von vormaligen Neu Ost-Preussen..., skala 1:150 000, Berlin 1806-1808 [dalej: Textor], sec. VIII.

15 ADP, AW z 1740 r., sygn. 263, k. 164v.

16 Regestr Diecezjów Franciszka Czaykowskiego czyli właściciele ziemscy w Koronie 1783-1784 [dalej: Regestr], wyd. K. Chłapowski, S. Górzyński, Warszawa 2006, s. 669.

17 Tabella miast, wsi, osad, Królestwa Polskiego, z wyrażeniem ich położenia i ludności [dalej: Tabella], t. 2, Warszawa 1827, s. 147.
Wiedza o dziejach obu osad pochodzi z nielicznych przekazów pisanych. Część z nich to autentyczne dyplomy wystawione przez książąt mazowieckich, potwierdzane następnie przez królów polskich. Zawierają one szczegółowe wiadomości o położeniu i specyfikacji nadań oraz o prawach i obowiązkach ich odbiorców. Inne przekazy pisane to krótkie streszczenia treści wystawianych, ale zazwyczaj niezachowanych aktów prawnych, zamieszczone w Metryce Mazowieckiej i Koronnej oraz w Matricularum Regni Poloniae Summaria. Siłą rzeczy zasób zawartych w nich wiadomości jest skromniejszy i enigmatyczny, co nie zawsze pozwala na niepodważalne powiązanie przekazu z konkretnym obiektem, w naszym przypadku z młynem i rudą-kuźnicą. Równie lakoniczne są informacje pochodzące $\mathrm{z}$ innych źródeł pisanych, powstałych głównie w dobie nowożytnej, na przykład z lustracji dóbr królewskich czy rejestrów poborowych. W niniejszym opracowaniu zostaną wykorzystane te z nich, które powstały w XV w. i w okresie wczesnonowożytnym.

Skromny stan podstawy źródłowej powodował, że interesującym nas osadom i istniejącym w nich obiektom przemysłowym nie poświęcono w literaturze przedmiotu zbyt wiele miejsca. Krótkie wzmianki o nich pojawiały się w pracach Jerzego Wiśniewskiego ${ }^{22}$ i Czesława Brodzickiego $^{23}$, przy czym nie wszystkie zawarte w nich ustalenia można obecnie podtrzymać. Ostatnio początek dziejów pierwszej miejscowości opracował Kazimierz Pacuski ${ }^{24}$.

18 Regestr, s. 669

19 K. Perthées, Mappa szczegulna województwa mazowieckiego [dalej: Perthées], skala 1:225 000, 1783; Textor, sec. VIII.

20 Tabella, t. 2, s. 148.

21 Zadziwiająco błędne jest omówienie tej nazwy przez Irenę Halicką: „n. top., wieś leży na bagnistym terenie nad rz. Skrodą”. I. Halicka, Nazwy miejscowe środkowej i zachodniej Białostocczyzny, topograficzne i kulturowe, Warszawa 1978, s. 65.

22 J. Wiśniewski, Początek i rozwój nowego osadnictwa w ziemi łomżyńskiej w końcu XIV i w XV wieku, „Studia Łomżyńskie”, 1, 1989 s. 68 .

23 C. Brodzicki, Ziemia tomżyńska, s. 64; tenże, Kościoty parafialne w ziemi wiskiej i łomżyńskiej do 1529 r., Warszawa 2003, s. 29 Wszystkie prace tego historyka amatora zawierają wiele błędnych i postulatywnych, pozaźródłowych informacji i ustaleń.

24 K. Pacuski, Początki osad w dzisiejszej gminie Mały Płock, w: Dzieje parafii, s. 172-174. 
Z zachowanych przekazów wynika, że wieś Ruda-Skroda powstała na obszarze nadania z 1416 r., a wieś Rudka-Skroda zapewne wokół położonego w pobliżu młyna Drągowskiego. Początek pierwszej wsi wiązany jest z osobą księcia Janusza I i datą 26 marca 1416 r. ${ }^{25}$ Wówczas to nadał on w Łomży rudnikowi z Przasnysza Janowi i jego synowi 10 włók chełmińskich położonych w dolnym biegu Skrody, powyżej jej lewego dopływu Puzowstoku ${ }^{26}$ (,super fluuio Skroda [et] Puzi Stok prope Nouigrod iacentes"). Było to nadanie na prawie rycerskim, $\mathrm{z}$ wyłączeniem prawa do zakładania barci i daniny miodowej, które książę zatrzymał dla siebie i swoich następców. W zamian Jan miał się stawiać na wyprawy wojenne konno, w pancerzu, z kuszą i w czepcu kolczym, zwanym kłobuczkiem $^{27}$. Jednocześnie książę potwierdził zakup przez Jana 5 włók chełmińskich (położonych obok nadanych) od Wieńczysława, Piotra i Mikołaja z Puszowlasu (Puzilass), późniejszych Cwalin (Małych), za kwotę pięciu kop groszy ${ }^{28}$. Włóki te zostały przeniesione z prawa polskiego (książęcego) na chełmińskie. Oznaczało to zwolnienie od wszystkich ciężarów prawa polskiego, z wyjątkiem obowiązku budowy i naprawy grodów.

Odbiorca nadania, rudnik z Przasnysza Jan, może być identyczny z Januszem z Młocka nad Łydynią w pobliżu Ciechanowa, który w latach 1414-1425 (przed 1416 r.) otrzymał od księcia Janusza I młyn zwany Rudą w Przasnyszu ${ }^{29}$. Nazwanie Jana rudnikiem (miner[ator]um) w dokumencie nadania nad Skrodą z 1416 r. sugeruje, że nadanie w Przasnyszu było nieco wcześniejsze.

Nadanie z 1416 r. obejmowało 10 włók (około $170 \mathrm{ha}$ ) położonych po lewej stronie Skrody, w widłach tej rzeki i Puzowstoku. Dokupione 5 włók (około 85 ha) znajdowało się

25 Kodeks Dyplomatyczny Polski, t. 1, wyd. L. Rzyszczewski, A. Muczkowski, Warszawa 1847, nr 165. Błędnie odczytano nazwę Puzi stok jako Piczystok oraz Puzilass jako Piczilas. Por. AGAD, perg. 771.

26 Dziś jest to bezimienny strumień uchodzący do Skrody około $2 \mathrm{~km}$ od jej ujścia do Pisy, między Rudą-Skrodą a Rudką-Skrodą.

27 Użyty w tekście taciński termin caleptra może oznaczać również hełm, szyszak. zapewne na północnym brzegu Puzowstoku, przy zachodniej granicy dóbr Puzowstok (późniejsze Cwaliny).

Sądząc z położenia nadanej ziemi, o jej wartości mogły decydować nie tylko przydatność rolnicza, ale również znajdujące się tu i za Pisą (w puszczy Zagajnica) pokłady rudy darniowej, które rudnik Jan właściwie ocenił. Można nawet założyć, że to on sam wybrał nadany obszar, bowiem wraz z synem zamierzali podjąć tu kopanie rudy i wytop żelaza. Działalność ta była motywowana rozpoczęciem przez księcia Janusza I od połowy lat 70. XIV w. wzmożonej akcji ponownego zasiedlania ziemi łomżyńskiej. Na początku XV w. objęła ona intensywnie Wysoczyznę Kolneńską. W związku z tym wzrosło zapotrzebowanie na żelazo - niezbędne przy budowie zabudowań, do produkcji narzędzi rolniczych oraz do rozwoju różnych rzemiosł w powstających miastach.

$\mathrm{Z}$ następnych lat brak jest jednak wiadomości o tym, czy na nadanych włókach założono wieś i czy podjęto działalność rudniczą. Zdaniem Jerzego Wiśniewskiego świadectwem zagospodarowania nadania z 1416 r. może być zapis z 1429 r. mówiący o nadaniu nieznanemu bliżej Marcinowi młyna położonego na Skrodzie, który zapoczątkował późniejszą wieś i powstałą po $1461 \mathrm{r}$. kuźnicę ${ }^{30}$. Moim zdaniem rzecz nie dotyczyła nadania z 1416 r., a odnosiła się do innego młyna nad tą rzeką. Zapis z 1429 r. dotyczy bowiem typowego nadania młyna zbożowego wraz z morgą ziemi uprawnej. Właściciel młyna miał prawo pobierać trzecią miarę od wszystkich mielonych zbóż, z zagwarantowaniem dla księcia i jego następców dwóch miar. W przypadku naprawy młyna młynarz miał ponosić koszty w wysokości jednego denara, a książę - dwóch. Ponadto młynarz, jako wykwalifikowany cieśla, miał

28 Por. przyp. 25; Kazimierz Pacuski uważa, że była to niska stawka, zapewne ze względu ma lesistość owych włók. Należy dodać, że znaczna jego część to teren podmokły, nienadający się do uprawy roli, ale z pokładami rudy żelaza. K. Pacuski, Początki osad, s. 172. 29 MK 3, k. 111v-112 (ok. 1456 r.).

30 Metryka Księstwa Mazowieckiego z XV-XVI w., t. 2: Księga oznaczona nr 334 z lat 1429-1433, wyd. A. Włodarski, Warszawa 1930, nr 80 (Pomniki Prawa, 6); J. Wiśniewski, Początek i rozwój, s. 56, 68. 
obowiązek naprawiać okna, stoły, ławy, stołki, drzwi i inne wyposażenie dworu książęcego, być może w Nowogrodzie.

Brak wiadomości o dziejach nadania z $1416 \mathrm{r}$. i o jego właścicielach trwa do 1439 r., kiedy to przy okazji nadania 2,5 włóki ziemi położonej nad Skrodą Piotrowi, synowi Mściwoja, wspomniano, że do tej pory trzymali je Klemens i Sułko ${ }^{31}$. Rzeczony Klemens jest, wedle wszelkiego prawdopodobieństwa, identyczny z Klemensem, rudnikiem $\mathrm{z}$ Przasnysza, znanym z 1450 r. ${ }^{32}$, działającym nieco później nad Skrodą. Jest w zasadzie pewne, że był on synem Jana, co wynika z dalszych dziejów tej wsi i jej właścicieli. Oznacza to tym samym, że obszar nadania z 1416 r. został zasiedlony, choć źródła pisane nie poświadczają nazwy założonej wsi. Kim był Sułko, nie udało się ustalić.

W 1461 r. Klemens, rudnik z Przasnysza, otrzymał kolejny dokument wystawiony 5 lutego w Łomży przez pozostających w niedziale synów Bolesława IV: Konrada, Kazimierza, Bolesława i Janusza ${ }^{33}$. Książęta nadali Klemensowi dział ziemi. Jego wartość wynosiła 500 dukatów w czystym złocie, które obdarowany wcześniej wpłacił. Dokument zawiera dokładny opis nowych dóbr, przylegających - jak można przypuszczać - do ojcowizny Klemensa, a położonych na lewym brzegu ujściowego odcinka Pisy, na południe od Puzowstoku. Zostały one opisane następująco: „,...] poczynając od narożnika (węgła) dóbr Chludnie do Biendugi, od Biendugi brzegiem rzeki Pisy aż do lasu Jaźwiny i wraz z tymże lasem, od Jaźwin prosto ścieżką aż do rzeki Skrody, następnie brzegiem Skrody do Puszów Lasu wzdłuż rzeki Skrody i wraz z tymże lasem Pusz, od Puszów Lasu aż do granicy (ściany) Cwalińskiej i Chludzieńskiej, wraz z młynem Drągowskim znajdującym się na rzece Skrodzie w tym dzia-

\footnotetext{
31 MK 3, k. 228-228v (ok. 1456 r.). Jedna z wsi sąsiadujących z Rudą-Skrodą na północnym wschodzie to właśnie Mściwuje.

32 Regesta historico-diplomatica Ordinis S. Mariae Theutonicorum, wyd. E. Joachim, W. Hubatsch, cz. 1, Göttingen 1948, nr 10277. Nieprawdziwa jest wiadomość podana przez Czesława Brodzickiego, że wzmianka ta zawiera informacje, iż Klemens był w tym roku rudnikiem w Rudzie-Skrodzie. C. Brodzicki, Ziemia tomżyńska, s. 64; tenże, Kościoty parafialne, s. 29. Bardziej ostrożny byt Kazimierz Pacuski, ale nie podał, że Klemens był rudnikiem w Przasnyszu. K. Pacuski, Początki osad, s. 173.
}

le położonym, w powiecie Nowogrodzkim, ze wszystkimi pożytkami istniejącymi w tymże dziale i pochodzącymi lub mającymi pochodzić w przyszłości z tegoż młyna, oraz że od teraz łaskawie nadajemy prawdziwym tytułem dziedzicznym w wieczyste posiadanie". Ponadto Klemens otrzymał „prawo wybudowania i postawienia od nowa kuźnicy czyli młyna rudnego na jego grobli oraz wycinania w naszych książęcych dobrach - tylekroć, ilekroć będzie o konieczne - drewna na potrzeby budowli i przewożenia go w celu odbudowania rzeczonego młyna rudnego". Uzyskał też Klemens zezwolenie "na wydobywanie rudy i wypalanie węgla wszędzie w naszych lasach, gdzie tylko będzie mógł poszukiwać". Owe lasy to bez wątpienia puszcza Zagajnica porastająca na prawym brzegu Pisy. Dowodzi tego następna część dokumentu, w której książęta zezwalają Klemensowi „na własny koszt zreperować, wybudować, odnowić most na rzece Pysz, dla potrzeb transportu rudy i węgli z naszych lasów, tylekroć, ilekroć będzie potrzeba”. Most znajdował się zapewne w pobliżu ujścia Skrody do Pisy, być może przy dzisiejszej wsi Dobrylas, skąd prowadzi droga do odległej o około $2,5 \mathrm{~km}$ Rudy-Skrody ${ }^{34}$. Za możliwość eksploatacji puszczy Klemens miał płacić rocznie "gay za tężę rudę i węgle po 10 kop [groszy, co równało się 20 florenom - E.K.-H.] monety i liczby polskiej corocznie na święto świętego Wojciecha [23 kwietnia - E.K.-H.], tak długo, jak w rzeczonych naszych lasach da się uzyskać rudę oraz wypalać i znajdować węgle".

Pozyskanie powyższych zezwoleń oznaczało, że pokłady rudy darniowej nad Skrodą były zbyt małe, a Klemens zamierzał rozwinąć produkcję żelaza na dużą skalę. Wymieniona w nadaniu binduga (przystań) położona na Pisie służyła spławianiu drewna i innych po-

33 AGAD, perg. 653; Matricularum Regni Poloniae Summaria [dalej MRPS], wyd. T. Wierzbowski, t. 4, vol. 3, Warszawa 1915, supl. nr 939.

34 Jan Powierski wadliwie zinterpretował ten zapis, pisząc, że rzecz szła 0 „zaangażowanie w eksploatacji puszczy daleko na wschodzie od miasta [Przasnysza - E.K.-H.]. J. Powierski, Prusowie, Mazowsze i sprowadzenie krzyżaków do Polski, t. 1, Malbork 1996, s. 185. Por. J. Senkowski, Skarbowość Mazowsza od końca XIV wieku do 1526 roku, Warszawa 1965, s. 78-79, przyp. 153. 
żytków leśnych, ale niewykluczone, że później także łupek i prętów-lasek żelaza oraz prostych narzędzi (odlewek do pługów) wyrabianych w rudzie-kuźnicy ${ }^{35}$.

Nie koniec na tym. Wraz z nadaniem ziemi Klemensowi przysługiwało prawo rozstrzygania wobec swoich poddanych „wszelkich spraw sądowych, jakiekolwiek wynikną $\mathrm{w}$ rzeczonym dziedzictwie i w jego sprawie, wznoszenie więzień i szubienic oraz powściąganie i karanie w granicach rzeczonego działu czyli dziedzictwa wszelkich krwawych zbrodni i pozbawienia członków, a także zbrodniczych wykroczeń wszelkiego rodzaju”.

Za wszystkie uzyskane uprawnienia Klemens był zobowiązany „do wyprawy wojennej z jednym koniem o wartości czterech kop, wraz z kuszą i kłobuczkiem, oraz do innych posług, które i inni ziemianie $\mathrm{w}$ podobnych dobrach zobowiązani są zwykli wypełniać i obsługiwać, do swadziebnego obojga płci dla nas i naszych następców, do prac przy grodach, do wykupu - co oby się nie zdarzyło - z niewoli nas i naszych następców, do odkupu ziemi i zakupu innej, tylekroć, ilekroć będzie [to] konieczne"36. Był to zatem w tej części typowy przywilej dla rycerstwa, odbiorców nadań liczących 10 włók, zobowiązujący ich do rozmaitych posług. Powyższy dokument był potwierdzany przez kolejnych władców, na przykład 25 stycznia 1548 r. przez Zygmunta Starego i 25 stycznia 1559 r. przez Zygmunta Augusta ${ }^{37}$.

Wybudowany przez Klemensa mlyn rudny służył do rozdrabniania rudy darniowej, a w rudzie-kuźnicy wytapiano żelazo. Znajdował się tu zapewne i piec kowalski, który służył do

\footnotetext{
35 W trakcie niszczenia stanowiska kuźniczego w Zbójnie natrafiono zarówno na narzędzia kuźnicze - „młot, cęgi i szczypce o długich ramionach" - jak i na liczne wyroby, takie jak „okucia stalowe (?!) do topat drewnianych, okucia mające uszy z dziurkami do umocowania przy pomocy gwoździ lub wkrętów (?!) z drewna [...] kroje do pługów, noże i inne przedmioty". T. Żurowski, Ślady średniowiecznej kuźnicy w Zbójnie, pow. Kolno, „Rocznik Białostocki”, 8, 1968, s. 415-416. Niestety, zabytki te nie są datowane, a przypuszczenie, iz pozyskane fragmenty naczyń glinianych miałyby pochodzić „nie wcześniej niż od XIII w.", nie zostało poparte żadną analizą archeologiczną. Badacz tego stanowiska nie był archeologiem, a architektem, który, korzystając z piastowanego stanowiska w ministerialnej służbie konserwatorskiej, nadużywał go, rozkopując i niszcząc liczne stanowiska archeologiczne.
}

produkcji prostych wyrobów żelaznych, a napęd koła wodnego wykorzystywano także do wtłaczania powietrza do miechów w piecach rudniczych i kowalskich oraz do napędu młota kowalskiego. Jednocześnie w 1461 r. Klemens stał się właścicielem młyna o nazwie Drągowski położonego nad Skrodą. Był to początkowo młyn zbożowy.

Przez kolejnych czterdzieści lat brak jest informacji o działalności kuźnicy, a i późniejsze są trudne do jednoznacznej interpretacji ${ }^{38}$. Oto w 1501 r. pojawia się szlachcic, rudnik Janusz. Był on jedną z osób trzymających w zastawie pobliską wieś Łosewo ${ }^{39}$. Następna wiadomość pochodzi z 1509 r., kiedy odnotowano, że właścicielem rudy-kuźnicy i powstałej przy niej osady Rwda był rudnik Jan (Johannes Ruth$n y k)^{40}$. Jest to zapewne ta sama osoba. Wydaje się jednak, że obie wiadomości nie dotyczą Rudy-Skrody, albowiem z treści zapisu z 1509 r. wynika, że rudnik Jan był winien nieznaną nam sumę pieniędzy za jakąś Rwdę Józefowi, rudnikowi z Nowogrodu. Sądzę, że była to inna, niezlokalizowana ruda (młyn i kuźnica) położona nad Skrodą, która pojawia się w źródłach ponownie w 1541 i 1545 r. ${ }^{41}$ Nie sposób ustalić, czy ów rudnik był skoligacony z właścicielami Rudy-Skrody.

Działalność potomków Klemensa nie ograniczała się do produkcji żelaza. Jeden $\mathrm{z}$ nich, Stanisław Skroda, otrzymał w 1538 r. nowy przywilej na wybudowanie młyna i folusza na Skrodzie we wsi Borek (osada młyńska), za co zapłacił 30 kop groszy ${ }^{42}$. Kolejny przedstawiciel tej rodziny, rudnik Mikołaj Skrodzki, jest poświadczony w 1546 r. jako współwłaściciel

\footnotetext{
36 Dziękuję panu Tomaszowi Płóciennikowi za nieocenioną pomoc w odczytaniu i przetłumaczeniu tego dokumentu.

37 AGAD, perg. 757; MRPS, t. 4, vol. 1, Warszawa 1910, nr 8158 Lustracja województwa mazowieckiego 1565 [dalej: Lustr. 1565], cz. 2, wyd. I. Gieysztorowa, A. Żaboklicka, Warszawa 1971, s. 223, poz. 149; MRPS, t. 5, vol. 1, Warszawa 1919, nr 2418.

38 Por. K. Pacuski, Początki osad, s. 173-174.

39 MK 18, k. 222v. Wieś ta leży na lewym brzegu Skrody, poniżej bagna Łosiowa Biel, a powyżej Rudy-Skrody.

40 AGAD, Księgi puttuskie grodzkie testamenta 1, 393.

41 Por. niżej, s. 91

42 MRPS, t. 4, vol. 3, nr 19020. W parafii Mały Płock położona była osada młyńska Borek przynależna do wsi Kąty, leżąca na południe od Kolna, koło Rudy-Skrody. Istnienie w niej młyna i folusza poświadcza
} 
wójtostwa w królewskim mieście Kolno ${ }^{43}$. $\mathrm{Z}$ wójtostwa tego (określonego jako położone na przedmieściu Kolna) Marcin i Wojciech Skrodzcy zrezygnowali 14 stycznia 1557 r. na rzecz Hieronima Modliszewskiego, starosty łomżyńskiego i kolneńskiego ${ }^{44}$. Wspomniani Marcin i Albert (Wojciech) Skrodzcy (Skroccy) uzyskali w 1559 r. kolejne potwierdzenie dokumentu z $1461 \mathrm{r}^{45}$

Kilka lat później, w 1565 r., ruda-kuźnica pojawia się w lustracji dóbr królewskich (w Rudzie-Skrodzie lub Rudce-Skrodzie). Dowiadujemy się tam, że jej właścicielem jest wspomniany Marcin Skrodzki posiadający dokument nadania z $1461 \mathrm{r}$. i że płaci on 20 florenów czynszu rocznego ${ }^{46}$. Wnoszenie opłaty do skarbu królewskiego wskazuje, że Marcin pozyskiwał rudę darniową i węgiel drzewny w Zagajnicy, zgodnie z przywilejem z $1461 \mathrm{r}$. $\mathrm{Z}$ tego powodu, mimo że ruda była własnością prywatną, opłaty z niej płynące wpisano do części lustracji odnoszącej się do Nowogrodu. To pozwala przyjąć, że eksploatowana część Zagajnicy podlegała starostwu łomżyńskiemu. Z dalszych przekazów wynika, że w okresie, który upłynął od pierwszego nadania obszaru ziemi, doszło do jego rozdrobnienia, bowiem w 1578 r. Ruda-Skroda miała już tylko 3 włóki ziemi (kmiecej), czyli nieco ponad 50 ha. Posadowiony w niej młyn miał jedno koło ${ }^{47}$.

W dokumencie z $1461 \mathrm{r}$. stwierdzono również, że w skład nadanych dóbr wchodził także młyn Dragowski, z którym wiązany jest początek wsi Rudka-Skroda. Z innego zachowanego przekazu wynika, że młyn ten powstał przed 1440 r., a więc jedno pokolenie wcześniej, i w tym roku stał się przedmiotem sprzedaży ${ }^{48}$. $Z$ treści zapisu dowiadujemy się, że wzniósł go Stanisław Drąg

lustracja z 1565 r. i wizytacja z 1647 r. zawarta w wizytacji z 1693 r. Lustr. 1565, s. 110; ADP, AW, 1693 r., k. 411. Młyn ten zapewne znajdował się powyżej Rudy-Skrody, za czym przemawia droga prowadząca ze wsi Kąty przez most na Skrodzie do wsi Dymki nad Pisą widoczna na mapie Textora. Textor, sec. VIII.

43 MRPS, t. 4, vol. 3, nr 22338.

44 Tamże, t. 5, vol. 1, nr 1967. Wcześniej, 18 marca 1556 r., Hieronim Modliszewski uzyskat od Zygmunta Augusta zgodę na wykupienie dwóch wójtostw: na przedmieściu Kolna i w Zabielu. Tamże, vol. 2, Warszawa 1961, nr 7402.

45 Tamże, vol. 1, nr 2418.
(Drank), otrzymawszy na niego przywilej, który uległ zniszczeniu. W 1440 r. przywilej został ponowiony i potwierdzony na prośbę Andrzeja, syna Stanisława, młynarza ze Skrody, dla niego i jego następców. Było to typowe nadanie młyna zbożowego, na mocy którego młynarz mógł pobierać trzecią miarę wszystkich mielonych tam zbóż. Nadanie obejmowało również 1 morgę ziemi uprawnej pod młyn (zapewne pod ogród warzywny) i drugą łąki. Tenże Andrzej, tak jak inni młynarze z sąsiedniej wsi książęcej Kąty ${ }^{49}$, był osadzony na prawie chełmińskim. Młyn ten - mimo że wzniósł go i posiadał Stanisław, a następnie Andrzej Drąg - jako wybudowany na obszarze przynależnym do tej wsi pozostawał własnością książęcą.

Potwierdzenie aktu nadania młyna było potrzebne Andrzejowi Drągowi, albowiem w tymże 1440 r. sprzedał on młyn zięciowi, Szczepanowi z Buczyna ${ }^{50}$. Następnie, w 1461 r., młyn przeszedł w ręce rudnika Klemensa, co potwierdzili książęta.

Dwie kolejne wzmianki są trudne do jednoznacznej interpretacji. Dowiadujemy się z nich, że w 1541 r. Jan Kołakowski kupił młyn Ruda, leżący nad Skrodą w powiecie kolneńskim, z rąk Mikołaja Drąga (Dranga $)^{51}$. Transakcję tę należy połączyć z kolejną. Oto cztery lata później, w 1545 r., kasztelan zakroczymski i starosta latowicki Aleksander Iłowski odkupił od tegoż Mikołaja Drąga królewską rudę (kuźnicę) żelazną, położoną $\mathrm{w}$ powiecie kolneńskim, niedaleko od Nowogrodu, zapewne obok wspomnianego mlyna ${ }^{52}$. Nie można wykluczyć, że owa Ruda to obiekt tożsamy ze wspomnianym w źródłach pisanych na początku XVI w. ${ }^{53}$ Nazwanie rudy-kuźnicy „królewską” („mineram regiam ferrariam”)

\footnotetext{
46 Lustr. 1565, s. 90.

47 ŹDz 16, s. 374

48 MK 3, k. 241v-242 (ck. 1456 r.).

49 Wieś ta leży w odlegtości około 3 km na północny wschód od Rudy-Skrody.

50 MK 3, k. 241v-242. Buczyno leżało w parafii czerwińskiej w powiecie ostrołęckim.

51 MRPS, t. 4, vol. 3, nr 22560, 20577.

52 Tamże, vol. 1, nr 7485.

53 Por. wyżej, s. 90.
} 
wskazuje, że obie transakcje dotyczyły zakładu produkcyjnego składającego się z młyna rudnego i rudy-kuźnicy położonych nad Skrodą, odrębnego od Rudy-Skrody i Rudki-Skrody, które były własnością prywatną, pozostającą nadal w rękach Skrodzkich, szlacheckiej rodziny rudników, potomków Klemensa. Nie wiemy tylko, czy ową rudę królewską zbudowała młynarska rodzina Drągów, czy też nabyła ją w nieznanym czasie, może po $1461 \mathrm{r}$. Po wykupieniu rudy Aleksander Iłowski miał ją posiadać dożywotnio ${ }^{54}$.

Młyny w Rudzie-Skrodzie i Rudce-Skrodzie istniały w XVII-XVIII w., przy czym w Rudzie-Skrodzie funkcjonowała nadal kuźnica żelaza i wydobywano tam rudę darniową ${ }^{55}$. Nie przynosiły one chyba zbyt wielkich dochodów, skoro w wizytacji parafii w Małym Płocku z 1693 r. zanotowano, że właściciele wsi Ruda powinni byli płacić dziesięcinę w wysokości sześciu złotych, ale od ponad dwudziestu lat nic nie uiszczają ${ }^{56}$.

Szczegółowych informacji o posadowieniu młynów nad Skrodą dostarczają mapy Karola Perthéesa, Johannesa Christopha von Textora, Kwatermistrzostwa i Daniela Gottloba Reymanna powstałe u schyłku XVIII w. i w pierwszej połowie XIX w. W obu wsiach odnajdziemy młyny położone poniżej stawów utworzonych na Skrodzie ${ }^{57}$. Były to tzw. stawy górne, z których wyprowadzono dodatkowe ramiona (kanały) rzeki, zwane młynówkami. Budowa stawów była konieczna wobec zmienności poziomu wody w Skrodzie i niewielkiego prądu tej rzeki. Należało zatem przegrodzić koryto rzeczki groblą z upustem, o której wspomina dokument z 1461 r., aby zgromadzić wodę w utworzonym w ten sposób stawie. Aby młyn

\footnotetext{
54 MRPS, t. 4, vol. 3, nr 20577.

55 Słownik geograficzny Królestwa Polskiego i innych krajów słowiańskich, t. 9, oprac. F. Sulimierski, B. Chlebowski, W. Walewski, Warszawa 1888, s. 889, nr 85: Ruda Skroda; tamże, t. 10, Warszawa 1889, s. 717: Skroda Rudka.

56 ADP, AW 1693 r., k. 405

57 Perthées; Textor, sec. VIII; Topograficzna karta Królestwa Polskiego, skala 1:126 000, tzw. mapa Kwatermistrzostwa, Warszawa (1839) 1843, kol. V, sek. II; D.G. Reymann, Topographische Specialkarte des Preussischen Staats und der angrenzender Lander, skala 1:200 000, Glogau 1844-1853, arkusz R: Ostrolenka.
}

mógł pracować, spuszczano wodę i jej prąd napędzał koło młyńskie posadowione nad upustem. Do obu młynów z obu stron Skrody prowadzity drogi, a korona grobli i mostek łączący obie jej części umożliwiały przejazd z jednej strony rzeki na drugą. Warto dodać, że na mapach Kwatermistrzostwa i Daniela Gottloba Reymanna w Rudzie (Skrodzie) oznaczono dwa młyny (koła). Młyn we wsi Rudka-Skroda był oznaczany jeszcze na mapach topograficznych z lat 60 . XX w..$^{58}$ Istniejąca tu do dziś jego drewniano-ceglana bryła (zbudowana w tzw. konstrukcji muru pruskiego) pochodzi z 1921 r. Nadal mieści się tu młyn, z tym tylko, że nie porusza go już koło wodne. Został on zadokumentowany w pracy Grażyny i Jerzego Aleksandra Balińskich ${ }^{59}$.

$\mathrm{Na}$ zakończenie wspomnę, że pokłady rudy żelaza zalegające w ujściowym odcinku Skrody i w puszczy były eksploatowane dowodnie jeszcze na przełomie XVIII i XIX w. Świadczy o tym petycja władz pruskich z 1807 r., w której zwrócono się do Rady Stanu Księstwa Warszawskiego o możliwość sprowadzania rudy darniowej z Małego Płocka, przeznaczonej dla położonej nad dawną granicą mazowiecką kuźnicy w Wądołku ${ }^{60}$. Prośba ta była konsekwencją przemian, które nastąpiły w administracji dóbr królewskich po trzecim rozbiorze Polski. Wówczas to Mały Płock - dawny ośrodek dóbr książęcych, a następnie królewskich - dekretem pruskim z 28 lipca 1796 r. wraz ze wszystkimi dobrami starościńskimi i królewskimi przeszedł na własność króla pruskiego. We wsi ulokowano siedzibę oddzielnej domeny, na którą złożyły się otaczające ją dawne królewszczyzny. Przedłożona w 1807 r. petycja musiała być konsekwencją pozyskiwania tu między 1795 a 1807 r. rudy

\footnotetext{
58 Mapa topograficzna N-34-104 [Ostrotęka], skala 1:100 000, [b.m.w.] 1960, pod nazwą Rudka-Skroda.

59 G. Balińska, J.A. Baliński, Młyny ziemi tomżyńskiej, Wrocław 2003 S. $258-259$.

60 Protokoły Rady Stanu Księstwa Warszawskiego, t. 1, cz. 2, wyd B. Pawłowski, Toruń 1962, s. 40, 57 (Fontes TNT, 51). Więcej wiadomości o kuźnicy w Wądołku, założonej w końcu XVIII w. tuż przy granicy z Mazowszem, zawiera artykuł Ryszarda Wojciecha Pawlickiego. R.W. Pawlicki, Wądotek - zapomniany ośrodek hutnictwa na Mazurach, „Znad Pisy”, 5, 1995, s. 37-48.
} 
darniowej i wywożenia jej do kuźnicy w Wądołku. Rzecz dotyczyła nie tyle złóż położonych na gruntach Małego Płocka, co na obszarze domeny, zapewne nad Skrodą przy ujściu Puzow- stoku i w Puszczy Kurpiowskiej. Transport rudy ułatwiała rozwinięta sieć drogowa Wysoczyzny Kolneńskiej, umożliwiająca dobre połączenia z pruskimi wsiami.

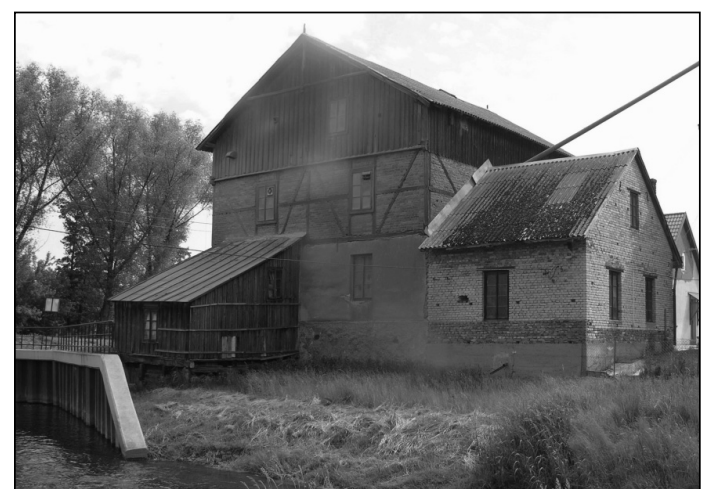

Fot. 1. Młyn w Rudce-Skrodzie, widok od południowego zachodu, czerwiec 2014 r. (fot. M. Skrzos)

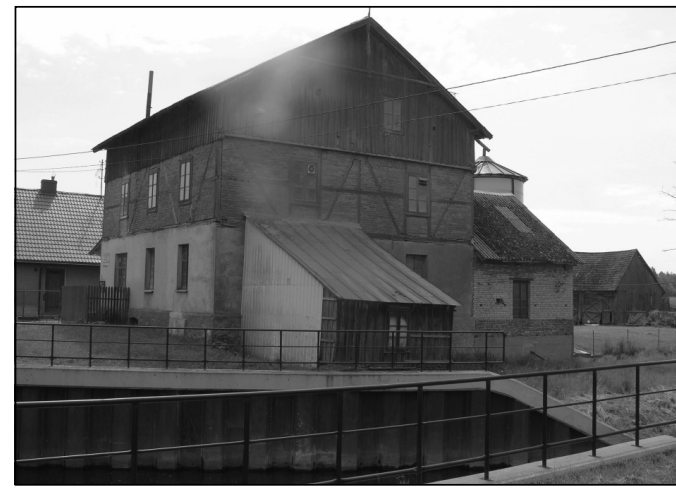

Fot. 2. Młyn w Rudce-Skrodzie, widok od pótnocnego zachodu (fot. M. Skrzos)

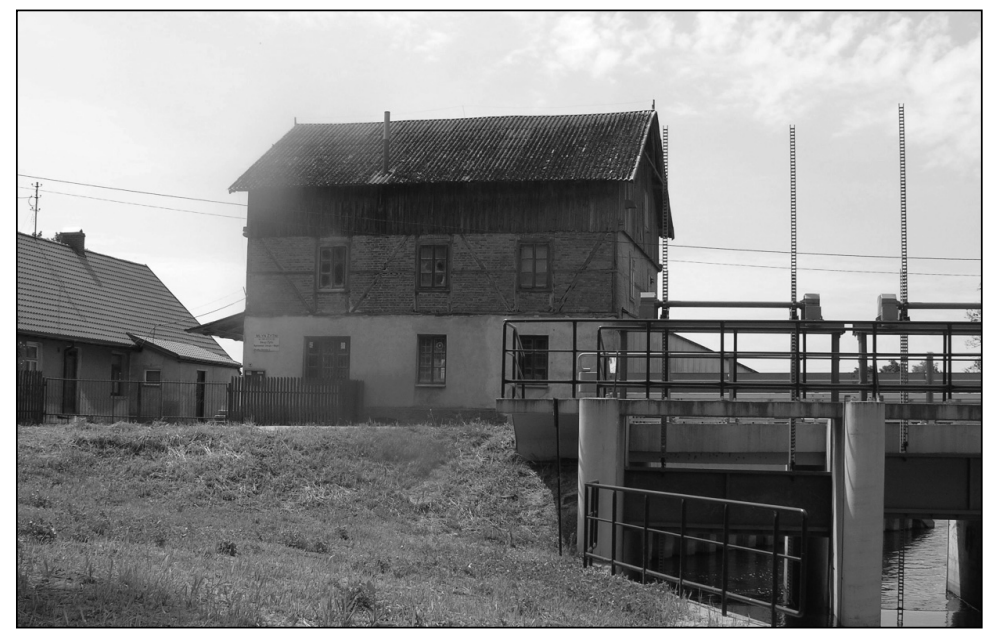

Fot. 3. Młyn w Rudce-Skrodzie, widok od pótnocy (fot. M. Skrzos) 


\section{ANEKS ŹRÓDŁOWY}

Eomża, 5 lutego $1461 r$.

Ksią̇ęta mazowieccy Konrad, Kazimierz, Bolestaw i Jan nadaja szlachetnemu Klemensowi, rudnikowi z Przasnysza, dziat ziemi nad rzekq Skrodq i mtyn Dragowski tam potożony wraz z immunitetem sadowym, zezwalają na budowe rudy-kuźnicy i mostu na Pisie, pozyskiwanie drewna na budowe mtyna, rudy żelaza i na wypat wegla drzewnego w swoich lasach, $w$ zamian za 500 dukatów w ztocie, stużbę wojskowa i inne, wymienione z nazwy powinności oraz czynsz za pozyskiwanie wspomnianych pożytków leśnych.

Or. Warszawa, $A G A D$, perg. nr 653.

Reg. MRPS, t. 4, vol. 3, supl. nr 939.

In nomine Domini amen. Ad perpetuam rei memoriam Conradus, Cazimirus, Boleslaus et Ioannes ${ }^{1}$ Dei gracia duces Mazovie, Russie terrarum necnon Warsschovienses, Wyschegradienses, Zacroczymenses, Czyech[an]novienses, Czernenses domini et heredes significamus tenore presencium tam presentibus quam futuris harum noticiam habituris quibus expedit generaliter universis quoniam confisi de fidelitate nobilis Clementis mineratoris de Przasznysz ${ }^{2}$ fidelis nostri sibi Clementi et successoribus illius legittimis sorte $[\mathrm{m}]$ terre bonorum ducatus nostri incipiendo ab angulo bonorum Chludny ${ }^{3}$ ad Byendugam $^{4}$, a Byenduga ripa fluuii Pysch ${ }^{5}$ usque ad silvam Yaszwyny ${ }^{6}$ et cum eadem silva, a Yaszwyny recto tramite usque ad fluvium Scroda ${ }^{7}$, demum rippa Scroda ad Puschyow $\mathrm{Las}^{8}$ per fluvium Scroda et cum eadem silva Pusch, a Puschyow Las usque ad parietem Czwalynowszka ${ }^{9}$ et Chlyudzyenska cum molendino Drągowski ${ }^{10}$ super fluvio Scroda in eadem sorte sitto in districtu Nowogrodiensi cum omnibus utilitatibus in eadem sorte existentibus et ex eodem molendino provenientibus ac proveniendis in futurum donavimus et dedimus, damus, donamus ac in verum titulum hereditarium ex nunc graciose conferimus et ascribimus in longum et latum velut huiusmodi sors terre in suis metis et limittibus extenditur cum utilitatibus universis nullis exceptis nec excipiendis perpetue et in evum obtinere et possidere. Qui Clemens fidelis noster hanc sortem terre redonavit nobis quingentis ducatis in auro puro. Et insuper prefatus Clemens cum successoribus illius legittimis ex prefatis bonis debebit et tenebitur nobis et successoribus nostris bellicam expedicionem complere uno equo valoris quatuor sexagenarum cum balista et clobuczek ac cetera servicia prout et ceteri terrigene in similibus bonis tenentur et consueti [sunt] complere et servire, nupcialia utriusque sexus nostri et successorum nostrorum, labores castrorum, redempcionem quod absit captivitatis nostre et successorum nostrorum, terre abempcionem et alie empcionem tociens quociens necesse fuerit. Cui quidem Clementi fideli nostro et successoribus illius legittimis dedimus et concessimus iudicia omnia quecumque eveniunt in et super prefata hereditate exercere, carceres et patibula erigere et cetera crimina obsanguinea et membrorum mutilacionem iuxta excessus criminales cuiuslibet maleficii in graniciebus sortis aut hereditatis prefate castigare et punire. Insuper ipsi Clementi fideli nostro et illius successoribus legittimis ex nostro libero consensu admisimus et concessimus mineram seu molendinum minere super ipsius aggere de novo edificandum et construendum ac robora pro edificiis in bonis nostri ducalibus excidendum et educendum tociens quociens necesse fuerit ad prefatum molendinum 
minere reedificandum. Demum ipsi Clementi et illius successoribus legittimis dedimus, concessimus et admisimus mineram accipere et carbones exurere ac disponere ubilibet in nemoribus nostris ${ }^{12}$, ubicumque perquiri poterit. Eidemque et prefato Clementi et illius successoribus legittimis admisimus et presentibus admittimus sua propria impensa pontem ${ }^{11}$ super fluvio Pysz reparare, construere, restaurare pro utilitate perduccionis minere et carbonum ex nemoribus nostris tociens quociens opus fuerit. Qui quidem Clemens fidelis noster cum illius legittimis successoribus nobis et successoribus nostris per decem sexagenas monete et numeri polonicalis gay de eadem minera et carbonibus dare et solvere super festum sancti Alberti ${ }^{13}$ singulis annis debebit, tenebitur et presentibus obligatur, donec minera recipi et carbones exuri ac inveniri poterint in prefatis nemoribus nostris. Quare sit licitum prefato Clementi fideli nostro et successoribus illius legittimis prefatam sortem hereditariam cum omnibus et singulis utilitatibus, fructibus, redditibus, proventibus, censibus, emolumentis et obvencionibus generaliter universis, quibuscumque nominibus nuncupentur, ad presens in dicta sorte hereditaria existentibus et accrescendis quomodolibet in futurum tenere, habere, regere, gubernare pacifice et quiete perpetuisque temporibus possidere necnon vendere, commutare, alienare, donare, obligare et ad usus suos beneplacitos convertere, prout sibi et illius successoribus legittimis melius et utilius videbitur expedire, nostra tamen et nostrorum successorum voluntate more solito principaliter requisita in premissis. In cuius rei testimonium sigillum preclari principis domini Boleslai ${ }^{14}$ felicis recordii ducis Mazovie, patris nostri clarissimi de certa nostra sciencia presentibus est subappensum. Actum et datum in Lomza ${ }^{15}$ feria quinta post festum Purificacionis Marie, anno Domini millesimo quadrigentesimo sexagesimo primo, presentibus magnifico strennuis nobilibusque dominis Ioanne de Wągrzynowo palatino Mazovie $^{16}$, Dobrogosto de Nowydwor Warschoviensi castellano ${ }^{17}$, Vincencio de Gyzycze marsalco ${ }^{18}$ aliisque plurimis nostris fidelibus fide dignis testibus circa premissa. Scriptum per manus Mathie de Tarnowo ${ }^{19}$ Ploczensis et Warszoviensis canonicii, rectoris parrochialis in Czersko $^{20}$ ecclesiarum et curie nostre cancelarii, qui presencia habuit in commissis.

1 Pozostający w niedziale synowie księcia Bolesława IV. 2 Przasnysz, miasto nad Węgierką, prawym dopływem Orzyca. 3 Chlud nie, wieś w hist. pow. kolneńskim, położona na prawym brzegu Czetny, prawego dopływu Narwi, obecnie w woj. podlaskim. ${ }^{4}$ Binduga, przystań nad Pisą, służąca do spławiania drewna. 5 Pisa, prawy dopływ Narwi. 6 Jaźwiny, las na lewym brzegu Pisy, nazwa zanikła. ${ }^{7}$ Skroda, lewy dopływ Pisy. 8 Puszów Las, nad Puzowstokiem, lewym dopływem Skrody, nazwa zanikła. ${ }^{9}$ Cwaliny, wieś w hist. pow. kolneńskim, położona nad Puzowstokiem, dzisiejsze Cwaliny Małe, w woj. podlaskim. ${ }^{10}$ Młyn zbożowy nad Skrodą, zapewne w dzisiejszej wsi Rudka-Skroda, w hist. pow. kolneńskim, obecnie w woj. podlaskim. ${ }^{11}$ Most na Pisie, zapewne koło dzisiejszej wsi Dobrylas, obecnie w woj. podlaskim. ${ }^{12}$ Późniejsza Puszcza Zagajnica. 1323 kwietnia. ${ }^{14}$ Bolesław IV, książę mazowiecki. 15 Łomża, miasto, stolica hist. ziemi łomżyńskiej, dziś w woj. podlaskim. 16 Jan Rogala z Węgrzynowa, whist. z. ciechanowskiej, obecnie w woj. mazowieckim, wojewoda czerski 1446-1461. K. Pacuski, Jan Rogala z Węgrzynowa, w: Polski Stownik Biograficzny, t. 31, red. E. Rostworowski, Wrocław 1988-1989, s. 389-391. 17 Dobrogost z Nowego Dworu (dziś Nowy Dwór Mazowiecki), h. Nałęcz, kasztelan warszawski 1433-1461. A. Borkiewicz-Celińska, Dobrogost z Nowego Dworu, w: Polski Stownik Biograficzny, t. 23, red. E. Rostworowski, Wrocław 1978, s. 360-361. 18 Wincenty z Giżyc, h. Gozdawa, w hist. z. gostynińskiej, obecnie w woj. mazowieckim, marszałek dworu ks. Bolesława IV do 1454 r., a następnie marszałek księstwa czersko-warszawskiego, kasztelan wiski w latach 1464-1467. K. Pacuski, Możnowładztwo i rycerstwo ziemi gostynińskiej w XIV i XV wieku. Studium z dziejów osadnictwa i elity władzy na Mazowszu średniowiecznym, Warszawa 2009, s. 96-98. 19 Maciej z (Różana) i Tarnowa, w hist. z. tomżyńskiej, obecnie w woj. podlaskim, pełnił różne funkcje od 1438 r., m.in. kanonika płockiego i warszawskiego, plebana kościoła parafialnego w Czersku i kanclerza księstwa czersko-warszawskiego od 1453 r. I. Sułkowska-Kurasiowa, A. Wolff, Maciej z Różana, w: Polski Stownik Biograficzny, t. 19, red. E. Rostworowski, Wrocław 1974, s. 35-36. ${ }^{20}$ Czersk, jedna ze stolic księstwa czersko-mazowieckiego, miasto, obecnie wieś w woj. mazowieckim. 


\section{Bibliografia:}

Źródła rękopiśmienne i niepublikowane:

Archiwum Diecezjalne w Płocku Akta Wizytacji z 1693 r., sygn. 47; Akta Wizytacji z 1714 r., sygn. 46; Akta Wizytacji z 1740 r., sygn. 263.

Źródła drukowane:

Kodeks Dyplomatyczny Polski, t. 1, wyd. L. Rzyszczewski, A. Muczkowski, Warszawa 1847.

Lustracja województwa mazowieckiego 1565, cz. 2, wyd. I. Gieysztorowa, A. Żaboklicka, Warszawa 1971.

Matricularum Regni Poloniae Summaria, wyd. T. Wierzbowski, t. 4, vol. 1, Warszawa 1910, t. 4, vol. 3, Warszawa 1915, t. 5, vol. 1, Warszawa 1919, wyd. J. Płocha, A. Rybarski, I. Sułkowska, t. 5, vol. 2, Warszawa 1961.

Metryka Księstwa Mazowieckiego z XV-XVI w., t. 2: Ksiega oznaczona nr 334 z lat 14291433, wyd. A. Włodarski, Warszawa 1930 (Pomniki Prawa, 6).

Polska XVI wieku pod wzgledem geograficzno-statystycznym, t. 5: Mazowsze, wyd. A. Pa-

Źródła kartograficzne:

Mapa topograficzna N-34-104 (Ostrotęka), skala 1:100 000, [b.m.w.] 1960.

Perthées K., Mappa szczegulna województwa mazowieckiego, skala 1:225 000, 1783.

Reymann D.G., Topographische Specialkarte des Preussischen Staats und der angrenzender Lander, arkusz R: Ostrolenka, skala 1:200 000, Glogau 1844-1853.

Literatura przedmiotu:

Balińska G., Baliński J.A., Mtyny ziemi tomżyńskiej, Wrocław 2003.

Borkiewicz-Celińska A., Dobrogost z Nowego Dworu, w: Polski Stownik Biograficzny, t. 23, red. E. Rostworowski, Wrocław 1978, s. 360-361.

Brodzicki C., Kościoty parafialne w ziemi wiskiej i tomżyńskiej do 1529 r., Warszawa 2003.

Brodzicki C., Ziemia tomżyńska do 1529 roku, Warszawa 1999.

Halicka I., Nazwy miejscowe środkowej i zachodniej Biatostocczyzny, topograficzne i kulturowe, Warszawa 1978.
Archiwum Główne Akt Dawnych w Warszawie Księgi pułtuskie grodzkie testamenta 1 . Metryka Koronna 3, 18, 335.

Dokumenty pergaminowe 653, 757, 771.

wiński, Warszawa 1895 (Źródła Dziejowe, 16).

Protokoty Rady Stanu Księstwa Warszawskiego, t. 1, cz. 2, wyd. B. Pawłowski, Toruń 1962 (Fontes TNT, 51).

Regesta historico-diplomatica Ordinis S. Mariae Theutonicorum, wyd. E. Joachim, W. Hubatsch, cz. 1, Göttingen 1948.

Regestr Diecezjów Franciszka Czaykowskiego czyli wtaściciele ziemscy $w$ Koronie 1783-1784, wyd. K. Chłapowski, S. Górzyński, Warszawa 2006.

Tabella miast, wsi, osad, Królestwa Polskiego, z wyrażeniem ich potożenia i ludności, t. 2, Warszawa 1827.

Textor J.Ch. von, Topographisch-Militaerische-Karte von vormaligen Neu Ost-Preussen..., sec. VIII, skala 1:150 000, Berlin 1806-1808.

Topograficzna karta Królestwa Polskiego, skala 1:126 000, Warszawa (1839) 1843, kol. V, sek. II.

Kowalczyk-Heyman E., Nikienki - o niebezpieczenistwach niesionych przez zbyt pochopne interpretacje toponomastyczne dla badań nad osadnictwem wczesnośredniowiecznym, „Onomastica”, 53, 2008/2009, s. 222-232.

Kowalkowski M., Blaski i cienie hutnictwa żelaza na ziemiach polskich. Refleksje historyczne, cz. 1: Od zarania dziejów do roku 1939, Częstochowa 1989.

Marczak E., Na rozdrożu kultur. Badania archeologiczne w Truszkach Zalesiu, gm. Kolno, woj. podlaskie, w: Stan badań archeologicznych na pograniczu polsko-biatoruskim od 
wczesnego średniowiecza po czasy nowożytne, red. H. Karwowska, A. Andrzejewski, Białystok 2006, s. 93-102.

Marczak E., Niezwykte odkrycie zwyktej ziemianki. Badania archeologiczne w Truszkach Zalesiu w 2010 roku, „Zeszyty Kolneńskie”, 5, 2010, s. 86-91.

Marczak E., „Nikienki” czyli Prusowie na Mazowszu? Wstępne wyniki badań archeologicznych $w$ Truszkach Zalesiu, woj. podlaskie, w: Przez granice czasu. Ksiega jubileuszowa poświęcona Profesorowi Jerzemu Gąssowskiemu, red. A. Buko, W. Duczko, Pułtusk-Warszawa 2008, s. 119-127 (Acta Archaeologica Pultuskiensia, 1).

Marczak E., Średniowieczne osady wśród tąk nad Wincenta. Zaplecze gospodarcze grodziska $w$ Truszkach Zalesiu, „Zeszyty Kolneńskie”, 2, 2007, s. 5-14.

Marczak E., Truszki-Zalesie, st. 4 („Nikienki”), woj. podlaskie. Badania w latach 2004-2005, 2007-2010, „Swiatowit”, 8 (49), fasc. B, 2011, s. 273-275.

Pacuski K., Jan Rogala z Wegrzynowa, w: Polski Stownik Biograficzny, t. 31, red. E. Rostworowski, Wrocław 1988-1989, s. 389-391.

Pacuski K., Maty Ptock. Zarys dziejów do 1526 roku, w: Dzieje parafii i kościoła pod wezwaniem Znalezienia Krzyża Świętego w Matym Ptocku, red. M. Przytocka, Mały Płock 2013, s. 45-58 (Folia Ecclesiastica Pultoviensia, 6).

Pacuski K., Możnowtadztwo i rycerstwo ziemi gostyninskiej w XIV i XV wieku. Studium zdziejów osadnictwa i elity władzy na Mazowszu średniowiecznym, Warszawa 2009.

Pacuski K., Początki osad $w$ dzisiejszej gminie Maty Ptock, w: Dzieje parafii i kościota pod wezwaniem Znalezienia Krzyża Świętego $w$ Matym Ptocku, red. M. Przytocka, Mały Płock 2013, s. 149-178 (Folia Ecclesiastica Pultoviensia, 6).

Pacuski K., Przytocka M., $Z$ dziejów Matego Ptocka, „Studia Łomżyńskie”, 15, 2004, s. 131-143.

Pawlicki R.W., Wadotek - zapomniany ośrodek hutnictwa na Mazurach, "Znad Pisy”, 5, 1995, s. 37-48.

Powierski J., Prusowie, Mazowsze i sprowadzenie krzyżaków do Polski, t. 1, Malbork 1996.

Radwan M., Rudy, kuźnice i huty żelaza w Polsce, Warszawa 1963.
Ratajczak T., Rzepa G., Górnictwo i hutnictwo darniowych rud żelaza na Mazurach i ziemi piskiej, „Znad Pisy”, 9, 2000, s. 192-207.

Ratajczak T., Skoczylas J., Polskie darniowe rudy żelaza, Kraków 1999.

Rauhut L., Studia i materiaty do historii starożytnego $i$ wczesnośredniowiecznego hutnictwa żelaza $w$ Polsce, w: Studia z dziejów górnictwa $i$ hutnictwa, t. 2, red. J. Pazdur, Wrocław 1957, s. 183-293.

Senkowski J., Skarbowośc Mazowsza od końca XIV wieku do 1526 roku, Warszawa 1965.

Stownik geograficzny Królestwa Polskiego i innych krajów stowiańskich, t. 9-10, oprac. F. Sulimierski, B. Chlebowski, W. Walewski, Warszawa 1888-1889.

Sułkowska-Kurasiowa I., Wolff A., Maciej z Różana, w: Polski Stownik Biograficzny, t. 19, red. E. Rostworowski, Wrocław 1974, s. $35-36$.

Twarowska E., Maty Ptock, gm. loco, stan. 2 [osada], w: Informator Archeologiczny. Badania rok 1979, Warszawa 1980, s. 263-264.

Twarowska E., Maty Ptock, gm. loco, stan. 2 [osada], w: Informator Archeologiczny. Badania rok 1979, Warszawa 1980, s. 167-168.

Twarowska E., Maty Ptock - legendy $i$ archeologia, „Ziemia Łomżyńska”, 2, 1986, s. 81-95.

Wiśniewski J., Dzieje osadnictwa w powiecie grajewskim do potowy XVI w., w: Studia $i$ materiaty do dziejów powiatu grajewskiego, t. 1, red. M. Gnatowski, H. Majecki, Warszawa 1975, s. 9-252.

Wiśniewski J., Początek i rozwój nowego osadnictwa $w$ ziemi tomżynskiej $w$ końcu XIV i wXV wieku, „Studia Łomżyńskie”, 1, 1989, s. 19-107.

Żurowski T., Ślady średniowiecznej kuźnicy $w$ Zbójnie, pow. Kolno, „Rocznik Białostocki”, 8, 1968, s. 415-416.

Żurowski T., Średniowieczna kuźnica $w$ Zbojnie, pow. Kolno, w: Sprawozdania z badań archeologicznych przeprowadzonych w $1966 r$. na obszarze województwa biatostockiego przez: Muzeum w Biatymstoku / Dziat Archeologiczny $i$ Woj. Konserwator Zabytków Archeologicznych / Państwowe Muzeum Archeologiczne $w$ Warszawie, Muzeum Regionalne $w$ Eomży, Białystok 1966, s. 26-28 (mps powielany na prawach rękopisu). 
Żurowski T., Zbójna, pow. Kolno [kuźnica], Żurowski T., Zbójno, pow. Kolno [kuźnica], w: Informator Archeologiczny. Badania rok w: Informator Archeologiczny. Badania rok 1968, Warszawa 1969, s. 378-380.

1967, Warszawa 1968, s. 384-385.

\section{Ruda-Skroda. A contribution to the history of iron ore mining in the Kolno Highland region in the Middle Ages and at the beginning of the modern period}

\section{Summary}

The present article is concerned with the problem which has been so far neglected by the scientists dealing with the Mazovian history. This is the history of iron ore mining on the example of two settlements, namely Ruda-Skroda and Rudka-Skroda, situated on the fringes of the Kolno Highland, on the river Skoda, the left-side tributary of the river Pisa. Luckily, two oldest acts initiating the establishment of both villages and ironworks, from 1416 and 1461 , were preserved. The documents determined the scope of rights and duties of the recipients of the rights, ore miner Jan from
Przasnysz and his son Klemens. An important element of those documents was the establishment of the right to exploit the Duke's forest Zagajnica by mining iron ore, wood burning and logging as well as building a bridge on the river Pisa, which facilitated transport. What can be interesting to the reader is the fact that ore mills and ironworks were situated in both localities until modern times, with another building of a mill in Ruda-Skroda, from the 19th c., existing till now, while the mill has been converted into an electrically powered grain mill.

Słowa kluczowe: średniowiecze, rudnictwo żelaza, Mazowsze, Wysoczyzna Koleńska, młyn wodny Keywords: Middle Ages, ore industry, Mazovia, Kolno Highland, watermill

dr hab. prof. nadzw. Elżbieta Kowalczyk-Heyman - zatrudniona w Instytucie Archeologii Uniwersytetu Warszawskiego. Specjalizuje się gtównie w średniowiecznych systemach obronnych, kształtowaniu granic, geografii osadnictwa i toponomastyce (e-mail: ekowalczyk@uw.edu.pl) 